\section{Biopharmaceutical sector performance, 1st quarter 2000}

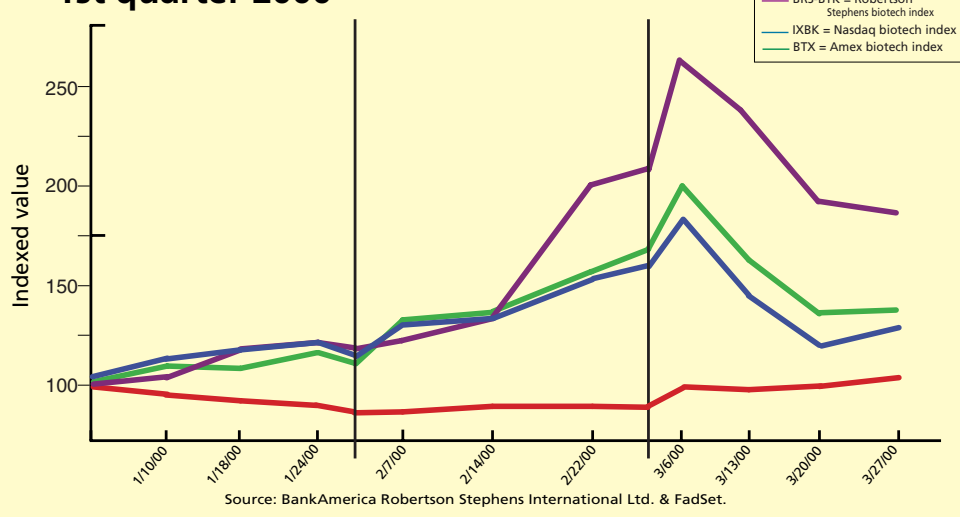

Initial public offerings, 1st quarter 2000

The first quarter saw 13 IPOs, raising a total of \$1.21 billion.

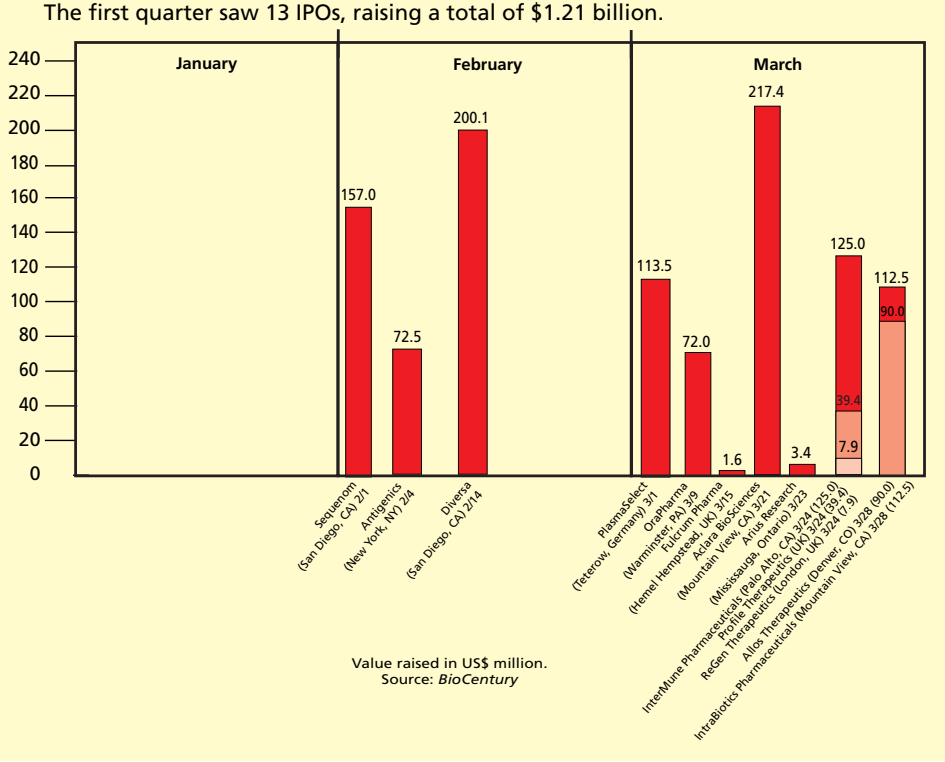

USDA testing lab planned

Officials from the US Department of Agriculture (USDA; Washington, DC) say they expect to have a specialized biotechnology reference laboratory up and running late this summer. The new laboratory, which will be part of the USDA Grain Inspection, Packers, and Stockyards Administration (GIPSA), will be located in Kansas City, $\mathrm{MO}$, and will focus on the use of PCR and immunologybased detection methods as diagnostic tools for testing biotechnology-derived grains and oils. Its functions will include evaluating and verifying validity of procedures used to detect and quantify modified traits in grains and oilseeds and establishing sampling procedures for testing these crops. GIPSA officials say that biotechnology has led to "increased consumer demand for conventional crops [that] has created a need for reliable testing methodologies to distinguish bioengineered from conventional crops." JF

\section{Public GM plant safety program}

A new European Union program, GMOCARE, has been set up to assess the safety of genetically modified food crops in relation to human health. It is a three-year effort comprising 11 European research institutes, which will use cellular-mapping technologies such as genomics, proteomics, and metabolite profiling to study the secondary and possibly unintended effects of genetic modification on metabolic pathways. GMOCARE will receive 2.6 million from the European Commission's Framework V program and an additional $\quad 1.1$ million in contributions from participating laboratories. It is hoped that GMOCARE's findings will complement those from other GM food-safety assessment projects-such as Entransfood, which uses animal models - and that the pooled research will lead the $\mathrm{EU}$ to define acceptable practice necessary to guarantee GM food crop safety.

\section{DuPont sues Monsanto}

DuPont (Wilmington, DE) has filed two lawsuits against rival agbio firm Monsanto (St. Louis, MO), turning up the heat in a growing legal dispute between the companies. The first, filed in federal court in Wilmington, alleges that Monsanto stole gene technology from its subsidiary Asgrow (which it acquired in 1996), which had licensed it from DuPont in the early 1990s. DuPont alleges that, as a result, Monsanto was able to introduce its Roundup Ready soybean two years ahead of schedule, thus destroying the market for DuPont's own herbicide-resistant soybean. Today, 35 million acres of cropland-about $50 \%$ of the US soybean crop-is grown from Monsanto's genetically modified Roundup Ready seed, compared with just 5 million acres of DuPont's herbicide-resistant STS soybean. The second lawsuit, filed in federal court in Florence, SC, charges that
Monsanto tried to monopolize cottonseed and herbicide markets. Monsanto spokesman Bryan Hurley says the lawsuits "are absolutely without merit" and were filed in response to a separate legal action in which Monsanto is suing a DuPont subsidiary, Pioneer Hi-Bred International, to invalidate a 1995 agreement that gives Pioneer access to Monsanto agricultural genes for a cheaper price than other seed companies.

EN

\section{The advisory committee strikes back}

In a strongly worded statement, the German Central Commission for Biological Safety (ZKBS), an expert group advising the Federal Ministry of Health on genetic engineering, has chastized the ministry for ignoring its advice. In March, ministry officials directed the Robert Koch
Institute to rescind the permit it had issued allowing the full-scale planting of Novartis Seeds' (Basel, Switzerland) Bt maize in Germany just weeks before plantings were due to begin (Nat. Biotechnol. 18, 374, 2000). Stressing their independence, members of ZKBS said the ministry's action had, in effect, bypassed the commission and, for the first time, ignored its recommendations without consultation. The ZKBS statement made it abundantly clear that the Health Ministry's decision was "in no way" based upon the recommendations of ZKBS. Furthermore, ZKBS said it could perceive no scientific basis for the decision. It criticized the experiments and analysis from the Öko-Institut in Freiburg-upon which the Ministry's decision had been based-as "unscientific and faulty." ZKBS has referred the Health Ministry's action to the European Commission (Brussels, Belgium), which will assess the scientific validity of the ministry's decision. 